\title{
Natural Attenuation Capacity Indicators for Groundwater Remediation to the Northeastern Cairo
}

\author{
A. A. Embaby', M. A. Sadek², R. A. Rayan² \\ ${ }^{1}$ Geology Department, Faculty of Science, Damietta University, Damietta, Egypt \\ ${ }^{2}$ Nuclear and Radiological Regulatory Authority, Naser City, Egypt \\ Email: embaby@du.edu.eg,m.sadek499@yahoo.com, Rafatrayan@yahoo.com
}

How to cite this paper: Embaby, A.A., Sadek, M.A. and Rayan, R.A. (2017) Natural Attenuation Capacity Indicators for Groundwater Remediation to the Northeastern Cairo. Journal of Geoscience and Environment Protection, 5, 152-168. https://doi.org/10.4236/gep.2017.54012

Received: February 22, 2017

Accepted: April 27, 2017

Published: April 30, 2017

Copyright $\odot 2017$ by authors and Scientific Research Publishing Inc. This work is licensed under the Creative Commons Attribution International License (CC BY 4.0).

http://creativecommons.org/licenses/by/4.0/ (c) (i) Open Access

\begin{abstract}
The natural attenuation capacity of groundwater is considered to be an important factor for remediation purpose, it is also important for surveying suitability in the early phases of siting hazardous facilities. The present work has been devoted to explore the natural attenuation capacity of the groundwater system northeast Cairo. Some indicators (hydrogeological, hydrochemical and isotopic) have been insighted to explore the system retardability against contaminant dispersion. Groundwater flow and contaminant transport have been pointed out using GOD index which varied from 0.04 to 0.28 reflecting high protectability. The isotopic contents $(18 \mathrm{O}, 3 \mathrm{H}$, and $14 \mathrm{C})$ showed a general comply with the GOD index and helped to delineate the sectors of high contaminate attenuation ability. Kelly index inferred significantly high adsorption potential on the aquifer clay content. The calcite and dolomite tend to precipitate on the aquifer contact providing a chance for specific contaminants to co-precipitate. The Eh-pH relation of the studied groundwater samples indicates high oxidation conditions and openness of the system. The attenuation capacity has been determined mathematically, it assumes the dispersive, advective, sorptive, and degradative processes acting on a solute in a one-dimensional flow system. The value of attenuation capacity increases by decreasing groundwater velocity and completely vanishes at a certain high velocity; determined for the relevant radioactive contaminants.
\end{abstract}

\section{Keywords}

Natural Attenuation Capacity, Indicators, Groundwater Remediation, Kelly Index, GOD Index, Northeast Cairo

\section{Introduction}

\subsection{Background}

The increasing of economic development and the rapidly growing population 
put a pressure on the Egyptian's natural resources. Northeast of Cairo is a target for development prospects (industrial, agricultural, urban, settlement ...) that stress the surface and groundwater resources both in quantity and quality, (Figure 1).

The groundwater remediation and its restoration recently shed the interest of many scientific activities. The methods used for groundwater remediation are either in situ or out-situe. Most of them are invasive and intentionally carried out [1]. However, groundwater systems may have some natural characteristics that mediate self-remediation processes.

Natural Attenuation can reduce the risk posed by contaminants in groundwater through destructive processes that destroy or transforms contaminants to less toxic forms and non-destructive processes that reduce the risk from the contaminants. These processes are physical, chemical, or biological and occur without human intervention [2]. These are distinguished into three types; A) Transport processes that include advection, dispersion, diffusion and sedimentation, B) Phase transfer processes that are responsible for movement between compartments such as Sorption and Volatilization, and C) Transformation processes are the only ones that effectively reduce the mass of contaminants where a transport processes mainly affect concentration and expenses [3].

The time required for lowering contaminant concentration (naturally) to the protective levels for human health and environment varies widely between different hydrologic systems, different chemical contaminants and varying amount of contamination [4].

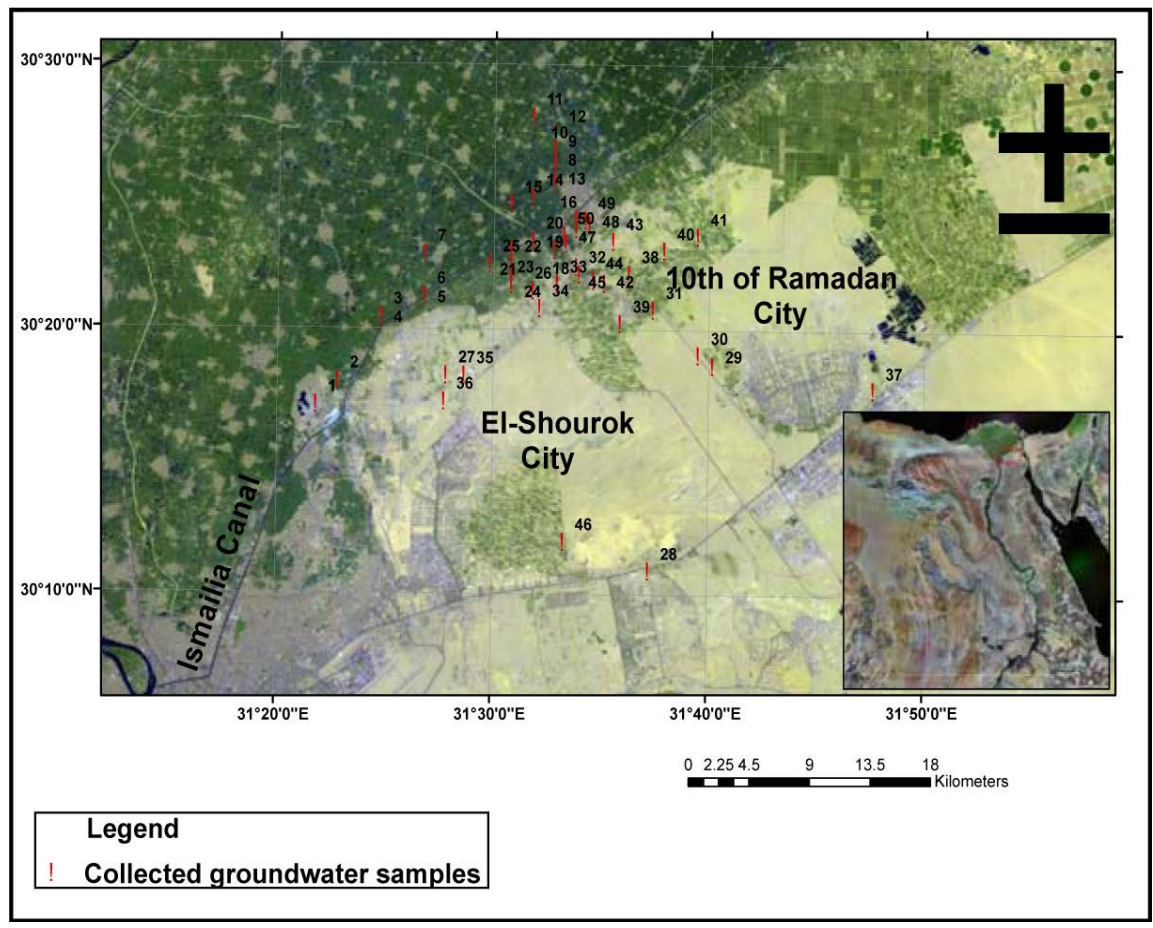

Figure 1. Location map of the study area (www.usgsearthexplorer.com), with the collected groundwater samples and boreholes. 
Application of natural attenuation of contaminants requires assurance that natural processes are acting efficiently, at a reasonable rate within optimized time-frame or otherwise enhanced remediation techniques are applied, [5]. The effectiveness of natural attenuation is determined by the rate of contaminant loading versus the rate of contaminant attenuation. When natural attenuation is not effective within a reasonable time frame, enhanced attenuation may be a vital alternative remedial strategy [6], and hence, the performance of natural attenuation process should be continually monitored.

Adequate site characterization lays the foundation for demonstrating the effectiveness of natural attenuation which is determined in the context of the site conceptual model, the supporting site data and the regulatory requirements [7]. The natural attenuation capacity of groundwater as being important for remediation purpose, it is also important for preferability survey considered in early phases of siting hazardous facilities [1].

Natural Attenuation is employed for groundwater remediation at an increasing number of sites to replace or augment engineered remediation. It has several advantages, among them: it is relatively non-intrusive, achievable, and it is of lower overall costs. As well as, it utilizes inherent natural processes, reduces the use of energy and creation of emissions or wastes from active processes. The indicated advantages of Natural Attenuation give relevance to using it in this work which aims at exploring the potential for groundwater remediation in an important aquifer to the northeast of Cairo. This information is important to measure the protectability of the system and to determine the critical parameters for protection

\subsection{Aim of the Work}

The present work some indicators for exploring the natural attenuation capacity for remediation of the groundwater, northeast Cairo. It functions an approach that integrates the results of hydrochemical analyses conducted on collected groundwater samples (major cations and anions), with inventoried data and information on geological, hydrogeological conditions, environmental isotopes analysis and finally simple analytical expression of radio contaminants attenuation. The indicators introduced in the investigation dealt, on one side, with lithogenic processes (e.g. adsorption, precipitation, permeability reduction ...), and on the other side with the flow and contaminant transport processes (advection, diffusion, dispersion) and decay.

\section{Geomorphologic, Geologic and Hydrogeologic Setting Geomorphological and Geological Setting}

The distribution of the main geomorphological features in the study area and its environ are shown in (Figure 2), as follow: Gebel Hamza Ridge, Heliopolis Basin, El-Khanka and Gebel-Asfer sand dunes and Nile Delta flood plain [8] [9] [10]. Along the existing ridges many of the fault plains, basalt rocks are exposed on the surface [11]. 


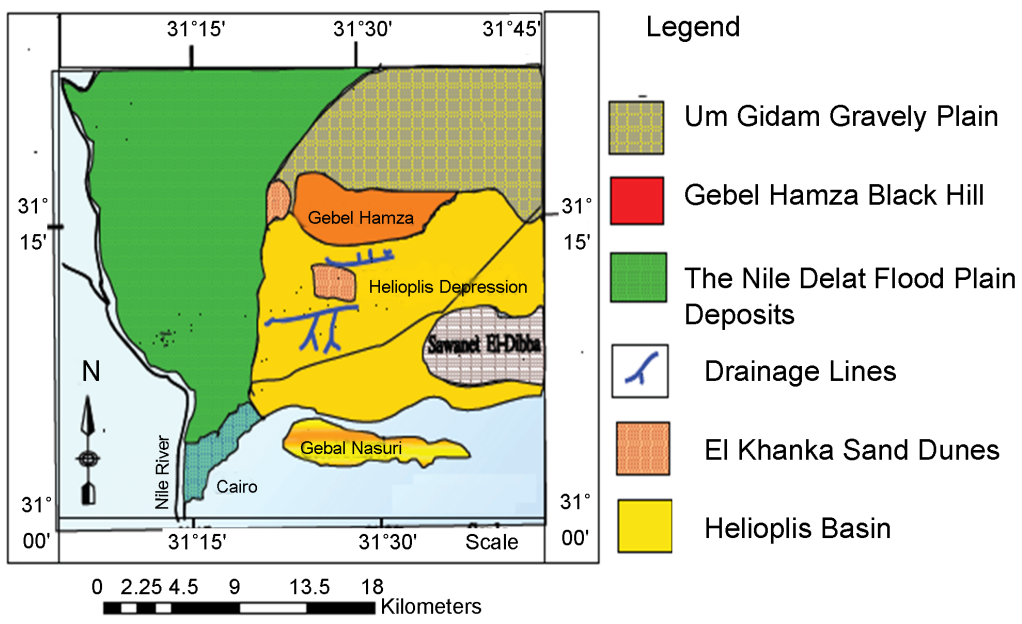

Figure 2. Distribution of different Geomorphological Units in the studied area, modified after [10].

The distributions of the different stratigraphic units in the northeast of Cairo area are shown in (Figure 3). These include sediments ranging in age from Eocene up to Holocene. The Holocene deposits are built up of sand sheets, drift sands, recent deltaic silts (average thickness is $5 \mathrm{~m}$ ) and the Pleistocene deposits are composed of unconsolidated fluvial sands and gravels with clay lenses (ranging in thickness from few meters to about $200 \mathrm{~m}$, increasing toward Ismailia canal) [11]. The Pleistocene sediments rest directly either on the Pliocene plastic clay or Miocene sandy limestone or Oligocene basalt. The Miocene sediments cover a large area in Cairo-Suez district, where most of the structural ridges are formed from them. These deposits are divided into two units; the lower is made up of marine deposits (sandy limestone, clay, marl and sand) increasing from west to east and the upper unit is non-marine section of white to grey, cross-bedded coarse grained poorly indurate quartz sand.

\section{Techniques and Approach}

In the studied area, groundwater occurs in two main water-bearing formations namely; Quaternary and Miocene. The Quaternary aquifer is mostly found under semi-confined conditions in Belbies area due to the presence of overlying clay bed and is found under unconfined conditions in Inshas area [12]. The depth to water ranges from $21 \mathrm{~m}$ (NE) to $91 \mathrm{~m}$ (SW). The groundwater flow direction is northeastward with a regional hydraulic gradient ranging between 50 and $60 \mathrm{~cm} / \mathrm{km}$ [11]. The Quaternary aquifer is mainly recharged from Ismailia canal as well as irrigation return flow. The Miocene aquifer is either found under unconfined or semi-confined conditions depending on the presence or absence of clay intercalation. Its recharge mainly takes place from precipitation during the past wet periods and to less extent from irrigation water and inflow from Pleistocene aquifer; it is discharging through production wells, [13]. Techniques and Approach to determine the potential of natural attenuation of contaminants in groundwater, an approach has been followed that satisfies the following: 


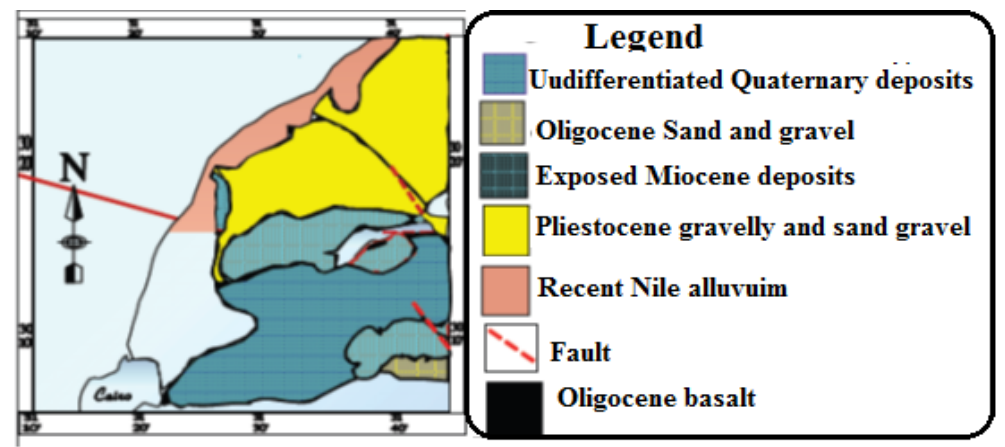

Figure 3. Geological Map of the study area, [10].

1. The conceptual modelling of the system to determine the input was designed, output and boundary conditions and the interactions of the different factors.

2. The major parameters of site characteristics and remediation processes that control the contaminant spread and toxicity and help to demonstrate the natural attenuation capacity were carefully collaborated.

3. The adoption of measures and indicators to be monitored, analyzed and assessed for determining the capacity of natural non-intervening remediation.

The followed approach fits the objective of the current work, where it mixes empirical aggregated data for describing present situation of the system and for getting information about its response. In this approach data are collected, analyzed and integrated to draw findings about aquifer conditions that resist the spread of contaminants. Accounts are taken to the expected sources of uncertainty related to data collected, analysis performed, and simulation assumptions.

Fifty groundwater samples have been collected from the two main aquifers in the study area (Quaternary and Miocene). Geographic locations, latitude, longitude and elevation of the water points were determined in the field with the help of GARMIN etrex GPS. All groundwater samples were collected in $1 \mathrm{~L}$ plastic bottles which were washed and triple-rinsed with distilled water and with the water of interest before sampling. For each groundwater sample a number of physico-chemical parameters were measured in field like TDS, $\mathrm{pH}$, and EC. While $\mathrm{Ca}^{2+}, \mathrm{Mg}^{2+}, \mathrm{Na}^{+}, \mathrm{K}^{+}, \mathrm{HCO}_{3}^{-}, \mathrm{CO}_{3}^{2-}, \mathrm{SO}_{4}^{2-}$ and $\mathrm{Cl}^{-}$were measured in the lab according of the standard methods [14].

The groundwater system in the study area has been conceptually modeled based on data and information inventoried about geological and hydrogeological conditions and relevant physical features. The hydrogeological parameters of the groundwater system (groundwater occurrence, depth to water, overlying sediments) have been deduced from 42 boreholes [11], tapping the Quaternary (21 boreholes) and Miocene (21 boreholes) aquifers. The isotopic content $\left({ }^{18} \mathrm{O},{ }^{3} \mathrm{H}\right.$, and ${ }^{14} \mathrm{C}$ ) of some selected borehole samples [Mohamed, 2009] have been analyzed for more insight on natural attenuation capacity determined.

Two indexes (GOD vulnerability index) and (Exchangeable Sodium Ratio index) have been calculated to infer the potentiality for pollutants retardation. Also, a mathematical expression of the capacity of the system to attenuate the con- 
taminates (natural attenuation capacity) has been determined.

The GOD index considers three of the major hydrogeological/environmental attributes, namely: (1) Groundwater occurrence, (2) Overlying upper layer lithology, (3) Depth to water. Each of these attributes is given a weighing factor reflecting the sensitivity of the system and process to it [15] [16]. These are also given rating factors, based on their values in the specific locations. The method of calculation of GOD index as well as its weighting and rating system and the categorization defined based on its values, are indicated in the work of Foster 1998. The data used in the current investigation for the GOD analysis are extracted from 42 boreholes [11] distributed in the study area.

The index of Exchangeable Sodium Ratio (Kelly index), has been calculated as proportional ratio of $\mathrm{Na}$ relative to $\mathrm{Ca}+\mathrm{Mg}$ concentration as follow [17]:

$$
\mathrm{ESR}=\frac{\mathrm{Na}}{\mathrm{Ca}+\mathrm{Mg}}
$$

The natural attenuation capacity of groundwater systems has been evaluated and determined based on hydrologic, hydrochemical and physical conditions (advection, dispersion, and adsorption and decay rates). The sum of dispersive, advective, sorptive, and degradative processes acting on a solute in a one-dimensional flow system is treated by the solute-transport equation, as follow:

$$
\frac{C}{t}=D \frac{{ }^{2} C}{x^{2}}-v \frac{C}{x}-\frac{K_{d}}{n} \frac{C}{x}-k C
$$

where $C$ is the concentration of the contaminant, $\mathrm{t}$ is the time (day), $D$ is the coefficient of hydrodynamic dispersion $\left(\mathrm{m}^{2} / \mathrm{d}\right), v$ is the velocity of ground-water flow $(\mathrm{m} / \mathrm{d}), \theta$ is bulk density, $K_{d}$ is a linear sorption distribution coefficient, $\mathrm{n}$ is porosity, and $\mathrm{k}$ is a first-order biodegradation rate constant $\left(d^{-1}\right)$ [18].

At a steady state and boundary conditions of $\mathrm{v}+=\mathrm{C} 0$ at $\mathrm{X}=0, \mathrm{C}=0$ at $\mathrm{X}$, the contininous concentration decrease away from the constant source, can be expresssesd through the following equation, which represents the solution of the previous equation [19] [20]:

$$
C(x)=\operatorname{Co} e \frac{v+\sqrt{v^{2}+4 D k}}{2 D}
$$

Equation (3) expresses the continuous reduction of contaminants in the aquifer. This has been used to simulate the natural attenuation capacity of the studied aquifer against six selected radioisotopes $\left({ }^{3} \mathrm{H},{ }^{14} \mathrm{C},{ }^{60} \mathrm{Co},{ }^{59} \mathrm{Ni},{ }^{99} \mathrm{Tc}\right.$, and $\left.{ }^{90} \mathrm{Sr}\right)$.

\section{Results and Discussion}

Table 1 and Table 2 show the results of hydrochemical analyses of the collected Quaternary and Miocene groundwater with some descriptive statistical analyses (minimum, maximum, mean and standard deviation). In addition to the isotopic content $\left({ }^{18} \mathrm{O},{ }^{3} \mathrm{H}\right.$, and $\left.{ }^{14} \mathrm{C}\right)$ of some selected boreholes samples [13], Table 3.

These results with the hydrogeological characteristics of the two aquifers have been used to deduce measures and indicators to for natural remediation.

The following Paragraphs will discuss the potentiality of the studied ground- 
Table 1. Chemical results of Quaternary groundwater samples.

\begin{tabular}{|c|c|c|c|c|c|c|c|c|c|c|}
\hline \multirow{2}{*}{$\begin{array}{c}\text { Serial } \\
\text { No. }\end{array}$} & \multirow{2}{*}{$\mathrm{pH}$} & \multirow{2}{*}{$\mathrm{EC}(\mu \mathrm{S})$} & \multirow{2}{*}{$\begin{array}{l}\text { TDS } \\
(\mathrm{mg} / \mathrm{l})\end{array}$} & \multicolumn{7}{|c|}{$(\mathrm{mg} / \mathrm{l})$} \\
\hline & & & & $\mathrm{Mg}^{2+}$ & $\mathrm{Na}^{+}$ & $\mathrm{K}^{+}$ & $\mathrm{CO}_{3}^{2-}$ & $\mathrm{HCO}_{3}^{-}$ & $\mathrm{SO}_{4}^{2-}$ & $\mathrm{Cl}^{-}$ \\
\hline 1 & 7.7 & 328.0 & 192.0 & 9.99 & 20 & 6 & 9 & 137.3 & 24.4 & 20.6 \\
\hline 2 & 7.8 & 327.0 & 187.0 & 9.20 & 22 & 6 & 12 & 128.1 & 21.2 & 18.0 \\
\hline 3 & 6.8 & 1123.0 & 749.0 & 15.00 & 160 & 20 & 9 & 186.1 & 243.3 & 143.9 \\
\hline 4 & 7.8 & 331.0 & 206.0 & 10.31 & 22 & 6 & 12 & 128.1 & 38.0 & 19.2 \\
\hline 5 & 8.0 & 414.0 & 273.0 & 12.20 & 32 & 7 & 9 & 134.2 & 68.7 & 29.6 \\
\hline 6 & 8.2 & 337.0 & 204.0 & 10.43 & 23 & 6 & 9 & 131.2 & 31.3 & 24.4 \\
\hline 7 & 7.8 & 2292.0 & 1436.0 & 63.38 & 300 & 13 & 24 & 430.1 & 520.0 & 205.7 \\
\hline 8 & 8.4 & 705.0 & 471.0 & 16.28 & 108 & 7 & 12 & 204.4 & 141.4 & 51.4 \\
\hline 9 & 8.3 & 917.0 & 603.0 & 26.27 & 136 & 9 & 18 & 170.8 & 180.0 & 110.6 \\
\hline 10 & 7.4 & 1197.0 & 669.0 & 29.78 & 130 & 18 & 15 & 250.1 & 156.9 & 133.7 \\
\hline 11 & 7.6 & 1102.0 & 788.0 & 40.00 & 126 & 10 & 9 & 176.9 & 280.0 & 154.2 \\
\hline 12 & 7.7 & 995.0 & 616.0 & 21.36 & 92 & 13 & 21 & 225.7 & 137.6 & 128.5 \\
\hline 13 & 8.5 & 1466.0 & 999.0 & 41.49 & 210 & 30 & 15 & 195.2 & 320.0 & 226.2 \\
\hline 14 & 8.5 & 370.0 & 554.0 & 25.96 & 124 & 7 & 15 & 195.2 & 164.8 & 79.7 \\
\hline 15 & 7.4 & 1010.0 & 706.0 & 32.63 & 120 & 9 & 6 & 286.7 & 250.0 & 74.6 \\
\hline 16 & 7.4 & 1231.0 & 734.0 & 30.97 & 165 & 8 & 9 & 326.4 & 141.0 & 149.1 \\
\hline 17 & 7.4 & 344.0 & 208.0 & 10.67 & 22 & 6 & 9 & 137.3 & 36.9 & 19.3 \\
\hline 18 & 8.1 & 1091.0 & 810.0 & 18.13 & 200 & 3 & 12 & 149.5 & 400.0 & 59.1 \\
\hline 19 & 8.0 & 328.0 & 179.0 & 8.40 & 20 & 6 & 9 & 131.2 & 18.9 & 16.7 \\
\hline 20 & 7.8 & 808.0 & 449.0 & 26.10 & 60 & 8 & 21 & 292.8 & 65.7 & 48.9 \\
\hline 21 & 7.7 & 556.0 & 270.0 & 10.00 & 30 & 8 & 18 & 176.9 & 19.8 & 38.6 \\
\hline 22 & 7.7 & 813.0 & 407.0 & 15.00 & 41 & 9 & 18 & 244.0 & 50.4 & 61.7 \\
\hline 23 & 7.9 & 2970.0 & 1849.0 & 59.89 & 420 & 9 & 12 & 118.9 & 800.0 & 372.8 \\
\hline 24 & 7.7 & 1279.0 & 657.0 & 22.88 & 135 & 3 & 18 & 298.9 & 110.4 & 133.7 \\
\hline 25 & 7.7 & 568.0 & 311.0 & 18.00 & 28 & 12 & 15 & 201.3 & 52.8 & 26.9 \\
\hline 26 & 7.5 & 774.0 & 425.0 & 4.53 & 140 & 4 & 0 & 122.0 & 100.0 & 101.6 \\
\hline 29 & 7.6 & 247.0 & 1779.0 & 30.84 & 180 & 8 & 0 & 134.2 & 355.0 & 179.9 \\
\hline 32 & 7.4 & 1461.0 & 916.0 & 18.93 & 230 & 8 & 0 & 82.4 & 242.0 & 290.5 \\
\hline 33 & 7.6 & 1359.0 & 893.0 & 31.75 & 1020 & 9 & 9 & 1340.2 & 1085.0 & 938.4 \\
\hline 34 & 7.9 & 4410.0 & 3258.0 & 14.14 & 44 & 7 & 105 & 164.7 & 85.0 & 32.1 \\
\hline 36 & 8.0 & 486.0 & 322.0 & 3.27 & 160 & 3 & 4 & 155.6 & 102.0 & 107.9 \\
\hline 43 & 7.5 & 695.0 & 465.0 & 44.21 & 720 & 11 & 9 & 1251.0 & 1015.0 & 668.5 \\
\hline 45 & 7.2 & 3780.0 & 2657.0 & 31.51 & 100 & 7 & 6 & 219.6 & 222.0 & 133.7 \\
\hline 47 & 7.2 & 1115.0 & 707.0 & 28.37 & 150 & 9 & 15 & 179.9 & 222.0 & 179.9 \\
\hline 48 & 7.6 & 1177.0 & 765.0 & 31.67 & 147.5 & 7 & 18 & 234.9 & 177.0 & 149.1 \\
\hline 49 & 7.9 & 1220.0 & 710.0 & 36.84 & 155 & 12 & 18 & 216.6 & 358.0 & 107.9 \\
\hline 50 & 7.5 & 1416.0 & 884.0 & 3.27 & 20 & 3 & 0 & 82.4 & 18.9 & 16.7 \\
\hline Min. & 6.8 & 247.0 & 179.0 & 63.38 & 1020 & 30 & 105 & 1340.2 & 1085.0 & 938.4 \\
\hline Max. & 8.5 & 4410.0 & 3258.0 & 23.90 & 160.90 & 9 & 14 & 223.1 & 228.8 & 145.5 \\
\hline Mean & 7.7 & 1109.2 & 765.1 & 14.30 & 198 & 5.11 & 16 & 204.2 & 258.6 & 183.8 \\
\hline
\end{tabular}


Table 2. Chemical results of Miocene groundwater samples.

\begin{tabular}{ccccccccccc}
\hline $\begin{array}{c}\text { Serial } \\
\text { No. }\end{array}$ & $\mathrm{pH}$ & $\mathrm{EC}(\mu \mathrm{S})$ & \multicolumn{7}{c}{$(\mathrm{mg} / \mathrm{l})$} \\
\cline { 7 - 11 } & & & $\mathrm{Ca}^{2+}$ & $\mathrm{Mg}^{2+}$ & $\mathrm{Na}^{+}$ & $\mathrm{K}^{+}$ & $\mathrm{CO}_{3}^{2-}$ & $\mathrm{HCO}_{3}^{-}$ & $\mathrm{SO}_{4}^{2-}$ & $\mathrm{Cl}^{-}$ \\
\hline 27 & 7.2 & 18990.0 & 499.7 & 434.1 & 3000 & 20 & 6 & 82.35 & 1087 & 6170.2 \\
28 & 7.0 & 9540.0 & 583.3 & 212.8 & 1200 & 12 & 6 & 97.6 & 1900 & 2185.3 \\
30 & 7.5 & 2320.0 & 36.9 & 20.3 & 570 & 7 & 6 & 115.9 & 430 & 642.7 \\
31 & 7.9 & 4170.0 & 37.6 & 19.7 & 450 & 6 & 0 & 152.5 & 321 & 527 \\
35 & 7.1 & 13580.0 & 121.5 & 40.2 & 780 & 11 & 9 & 140.3 & 930 & 835.6 \\
37 & 6.9 & 9650.0 & 705.7 & 385.0 & 1750 & 28 & 12 & 128.1 & 2616 & 3290.8 \\
38 & 7.7 & 3080.0 & 521.8 & 142.2 & 1400 & 11 & 0 & 42.7 & 1435 & 2493.8 \\
39 & 7.4 & 4680.0 & 85.3 & 33.6 & 370 & 13 & 12 & 189.1 & 237 & 565.6 \\
40 & 7.9 & 4830.0 & 200.5 & 47.8 & 760 & 7 & 3 & 109.8 & 519 & 1285.5 \\
41 & 7.5 & 5380.0 & 116.3 & 36.9 & 960 & 6 & 12 & 131.2 & 970 & 1079.8 \\
42 & 7.6 & 2465.0 & 465.8 & 58.6 & 800 & 7 & 12 & 228.8 & 1964 & 719.9 \\
44 & 7.0 & 1444.0 & 115.6 & 47.0 & 330 & 14 & 15 & 119.0 & 385 & 529.6 \\
46 & 7.6 & 2477.0 & 7.4 & 3.3 & 160 & 3 & 4.5 & 155.6 & 102 & 108.0 \\
Min. & 6.9 & 1444.0 & 89.1 & 33.9 & 185 & 8 & 9 & 94.6 & 425 & 195.4 \\
Max. & 7.9 & 18990.0 & 94.2 & 37.6 & 420 & 11 & 6 & 176.9 & 640 & 390.8 \\
Mean & 7.4 & 6354.3 & 465 & 7.4 & 3.3 & 160 & 3 & 0 & 42.7 & 102 \\
\hline & & & & & & & & & & \\
\hline
\end{tabular}

Table 3. Isotopic Data of selected borehole groundwater samples [20].

\begin{tabular}{|c|c|c|c|}
\hline Serial No. & $\delta^{18} \mathrm{O}(\% \mathrm{o})$ & ${ }^{3} \mathrm{H}$ (T.U.) & ${ }^{14} \mathrm{C}(\mathrm{pmc})$ \\
\hline 1 & 2.42 & 9.9 & \\
\hline 2 & 2.43 & 9.83 & 108 \\
\hline 4 & 0.67 & & \\
\hline 5 & 3.78 & & 98 \\
\hline 6 & 5.89 & 8.5 & \\
\hline 9 & 3.32 & 9.97 & \\
\hline 11 & 2.49 & & 102 \\
\hline 19 & -0.83 & 0.4 & 65 \\
\hline 21 & -4.51 & & \\
\hline 24 & -6.9 & & \\
\hline 26 & -7.09 & 1.99 & \\
\hline 27 & -7.96 & & \\
\hline 28 & -8.62 & & \\
\hline 29 & -7.16 & & \\
\hline 30 & -2.02 & 2.26 & \\
\hline 32 & -0.17 & 2.65 & \\
\hline 35 & -0.83 & 1.03 & \\
\hline 36 & 2.75 & & 101 \\
\hline 37 & 1.71 & & 109 \\
\hline 38 & -0.47 & & 77 \\
\hline 39 & -1.58 & 0.4 & 76 \\
\hline
\end{tabular}


water to inhibit the pollutants distribution and to suppress their toxicity.

\subsection{Unsaturated Zone Retardability of Contaminant Transport}

The index and overlay methodology exemplified by GOD index has been functioned to investigate the retardability of the groundwater contaminants through unsaturated zone in the study area.

The values of the index vary in the range from (0.04 to 0.28), (Figure 4). These values are all related to the category of negligible to low vulnerability to contamination. The thickness of the unsaturated zone above water table and its clay content which retards the flow by low permeability and attenuates the pollutants by adsorption, increase the efficiency of pollutants retardation and remediation.

The isotopic content $\left({ }^{18} \mathrm{O},{ }^{3} \mathrm{H}\right.$, and $\left.{ }^{14} \mathrm{C}\right)$ of the selected boreholes, Table 2 , have been insighted in this work as a measure for retardability potential of contaminants in the study area. $\delta^{18} \mathrm{O}$ values cover a wide range between $5.89 \%$ and $-8.62 \%$ reflecting different recharge sources of different renewability. The more renewable recharge comes from Nile water and irrigation return $\left(\delta^{18} \mathrm{O}=\right.$ $+2.39 \%$ and $\delta^{18} \mathrm{O}=+4.9 \%$, respectively) [21] [22], the less renewable recharge comes from pluvial times water $\left(\delta^{18} \mathrm{O}=-9.7 \%\right.$ ) [23] [24]. The retardability of aquifer recharge is tested using tritium and radiocarbon data. The tritium content is separated into two groups in the range between 0.4 and 9.97 T.U. The group of high tritium content is related to the Quaternary aquifer and the other one is related to Miocene. ${ }^{14} \mathrm{C}$ of the samples covers the range between 65 to 109 pmc reflecting the contribution of different proportions of old water to present day recharged water.

The scatterplots of ${ }^{3} \mathrm{H}$ and ${ }^{14} \mathrm{C}$ on one side and GOD index on the other side are shown in (Figure 5 and Figure 6). The patterns show a general comply between GOD parameters and isotopic composition where, the low GOD values which correspond to high protectability are generally attached to low ${ }^{3} \mathrm{H}$, and low ${ }^{14} \mathrm{C}$ values that point out to high retard ability of groundwater flow and less renewability of aquifer recharge. The high ${ }^{3} \mathrm{H}$ and ${ }^{14} \mathrm{C}$ values point out to more

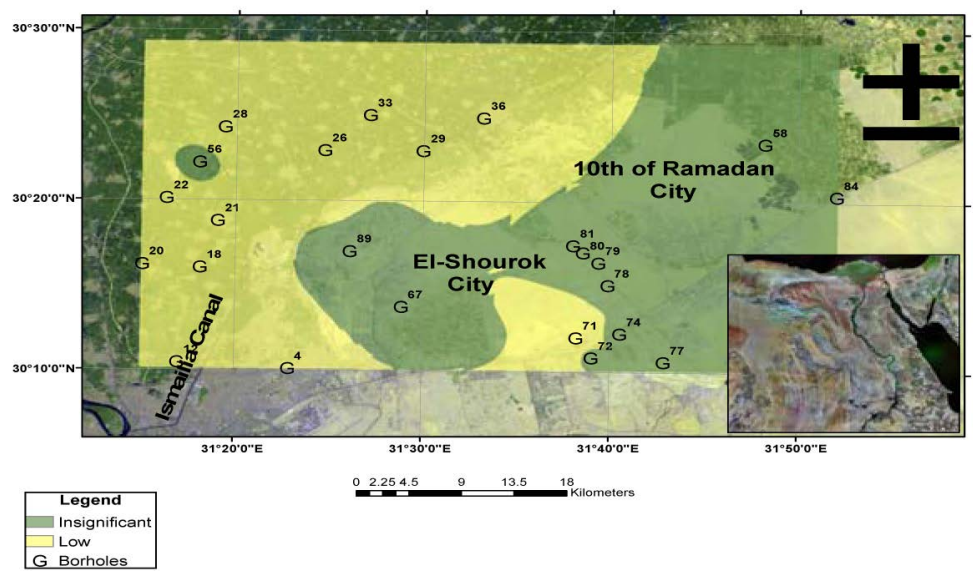

Figure 4. GOD index vulnerability map. 


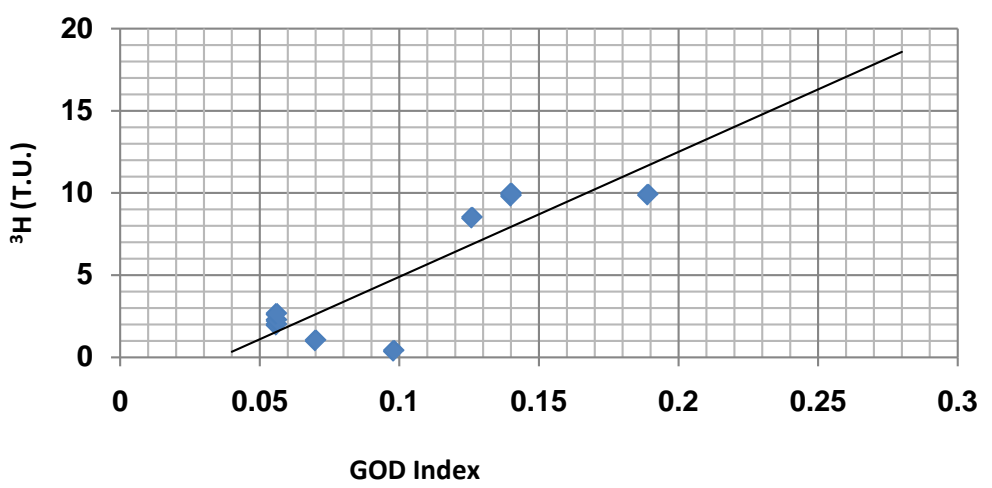

Figure 5. 3H (TU) vs. GOD index.

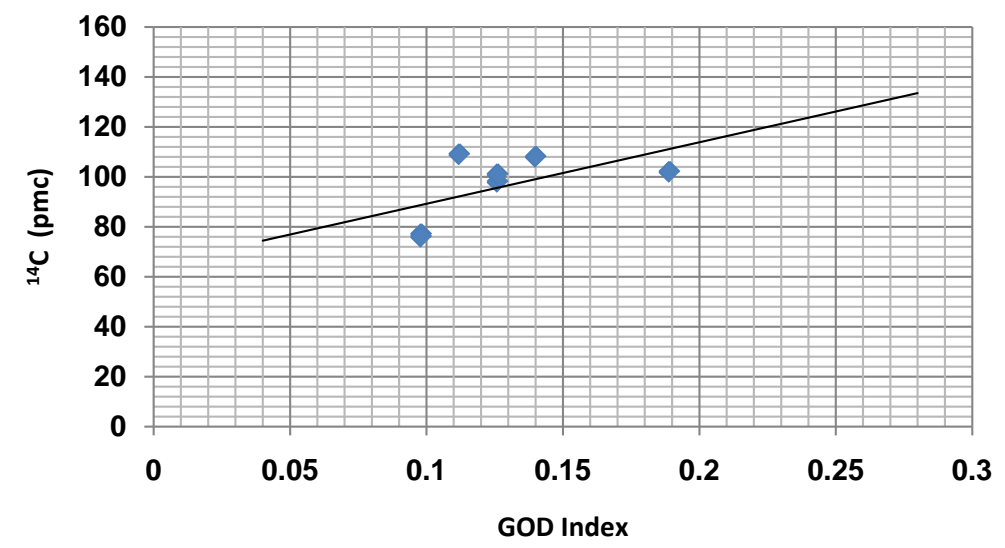

Figure $6 .{ }^{14} \mathrm{C}(\mathrm{pmc})$ vs. GOD index.

renewable higher rechargeable water from Nile water system.

\subsection{Hydrogeochemical Indicators for Pollutants Attenuation Potential}

\subsubsection{General Hydrochemical Characters}

The TDS of the Quaternary groundwater samples shows values in the range from 311 to 3258 ppm, on the other hand TDS varies between 993 and 11259 ppm. About $70 \%$ of the samples (Quaternary aquifer and some samples mixing between Miocene and Quaternary) has TDS values below 1500 ppm (i.e. fresh water), the rest are brackish with three samples of them are saline. The brackish and saline water are developed under the conditions of high clay content and high residence time in the area to the east (Miocene aquifer).

The concentration of the major ions shown in Table 1 and Table 2 represent attributes for defining water types, hydrochemical facies and salinity evolution. The Miocene groundwater's are all related to $\left(\mathrm{SO}_{4}, \mathrm{Cl} / \mathrm{Na}, \mathrm{K}\right)$ hydrogeochemical facies reflecting a high stage of salts evolution. The groundwater samples of the Quaternary aquifer have, on the other hand more variant hydrogeochemical facies (e.g. $\left(\mathrm{HCO}_{3} / \mathrm{Ca}, \mathrm{Mg}\right),\left(\mathrm{SO}_{4}, \mathrm{Cl} / \mathrm{Ca}, \mathrm{Mg}\right)$ and $\left(\mathrm{SO}_{4}, \mathrm{Cl} / \mathrm{Na}, \mathrm{K}\right)$ in about $15 \%$, $25 \%$ and $60 \%$ of the samples, respectively). These water types reflect a, moderate and high stage of mineralization. 


\subsubsection{Sorption and Cation Exchange Processes}

Sorption process and cation exchange refers to the reversible uptake of ionic species at charged surface sites like that dominated by clay minerals. When the concentrations of sodium are high in groundwater, sodium ions tend to be absorbed by clay particles, displacing $\mathrm{Mg}^{2+}$ and $\mathrm{Ca}^{2+}$ ions.

The calculated values of this index in the study area are shown in Table 1; all Miocene samples and about $51 \%$ of the Quaternary aquifer have values above 1, revealing lower permeability and eventually poor internal drainage soil, which optimizes the attenuation of groundwater flow and contaminant transport and emphasizes the protectability of the system [25].

In order to investigate the occurrence of cation exchange reaction in the studied groundwater system, $\left(\mathrm{Ca}^{2+}+\mathrm{Mg}^{2+}\right)-\left(\mathrm{HCO}_{3}^{-}+\mathrm{SO}_{4}^{2-}\right)(\mathrm{meq} / \mathrm{l})$ was plotted against $\left(\mathrm{Na}^{+}+\mathrm{K}^{+}\right)-\mathrm{Cl}^{-}(\mathrm{meq} / \mathrm{l})$, (Figure 7). If cation exchange is an important mechanism controlling the ionic composition, the relation between the two parameters $\left(\mathrm{Ca}^{2+}+\mathrm{Mg}^{2+}\right)-\left(\mathrm{HCO}_{3}^{-}+\mathrm{SO}_{4}^{2-}\right)$ and $\left(\mathrm{Na}^{+}+\mathrm{K}^{+}\right)-\mathrm{Cl}^{-}$would exhibit an inverse proportional evolution [26]. The investigated groundwater samples are plotted along a straight line of slope $=-0.89$ indicating that ion exchange has taken place in the groundwater, (Figure 7).

\subsubsection{Precipitation Process}

The precipitation of salts from groundwater on the rock matrix may co-precipitate some contaminants and also causes reduction of soil and sediment permeability. Saturation Indexes (SI) of the relevant phases in the studied groundwater system (Anhydrite, Calcite, Dolomite, Gypsum, and Halite) have been calculated using hydrochemical model, [27], to test the effects of precipitation mechanisms, Table 4 and Table 5. The samples that have positive SI values with respect to a given phase tend to precipitate it on the rock due to oversaturation, while that having negative SI tend to continue dissolving it due to under saturation. The calculated saturation indexes of the collected groundwater samples show positive values in about $54 \%$ of the Miocene samples for calcite and in $85 \%$ for dolomite, on the other hand, about $24 \%$ and $89 \%$ of the Quaternary shows oversaturation with respect to calcite and dolomite, respectively. Revealing that both calcite and

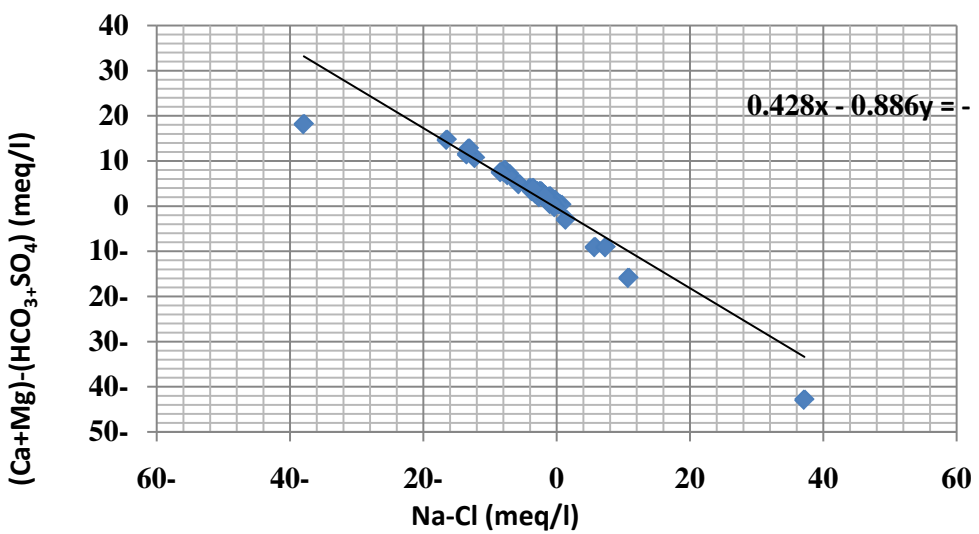

Figure 7. Cation Exchange Diagram $\left(\mathrm{Ca}^{2+}+\mathrm{Mg}^{2+}\right)-\left(\mathrm{HCO}_{3}^{-}+\mathrm{SO}_{4}^{2-}\right)($ meq/l) vs. $\left(\mathrm{Na}^{+}-\mathrm{Cl}^{-}\right)(\mathrm{meq} / \mathrm{l})$ for the collected groundwater samples. 
Table 4. Saturation indices of the collected groundwater samples.

\begin{tabular}{|c|c|c|c|c|c|}
\hline Serial No. & Anhydrite & Calcite & Dolomite & Gypsum & Halite \\
\hline 1 & -2.71 & -0.95 & 0.77 & -2.42 & -7.9 \\
\hline 2 & -2.7 & 0.09 & 0.92 & -2.5 & -7.9 \\
\hline 3 & -1.65 & -0.65 & -0.63 & -1.36 & -6.29 \\
\hline 4 & -2.52 & 0.08 & 0.95 & -2.23 & -7.95 \\
\hline 5 & -2.17 & 0.38 & 1.5 & -1.88 & -7.6 \\
\hline 6 & -2.6 & 0.46 & 1.72 & -2.31 & -7.82 \\
\hline 7 & -1.37 & 0.76 & 2.66 & -1.08 & -5.87 \\
\hline 8 & -2.1 & 0.72 & 2.46 & -1.81 & -6.86 \\
\hline 9 & -1.99 & 0.62 & 2.39 & -1.7 & -6.43 \\
\hline 10 & -1.87 & 0.07 & 1.16 & -1.58 & -6.38 \\
\hline 11 & -1.55 & 0.2 & 1.4 & -1.26 & -6.34 \\
\hline 12 & -1.75 & 0.52 & 1.74 & -1.46 & -6.54 \\
\hline 13 & -1.68 & 0.95 & 3.07 & -1.39 & -5.96 \\
\hline 14 & -2 & 0.87 & 2.87 & -1.71 & -6.61 \\
\hline 15 & -1.63 & 0.14 & 1.26 & -1.34 & -6.67 \\
\hline 16 & -1.89 & 0.2 & 1.38 & -1.6 & -6.23 \\
\hline 17 & -2.51 & -0.29 & 0.22 & -2.22 & -7.94 \\
\hline 18 & -1.66 & 0.34 & 1.61 & -1.37 & -6.56 \\
\hline 19 & -2.79 & 0.29 & 1.28 & -2.5 & -8.04 \\
\hline 20 & -2.11 & 0.67 & 2.21 & -1.82 & -7.13 \\
\hline 21 & -2.61 & 0.33 & 1.23 & -2.32 & -7.51 \\
\hline 22 & -2.11 & 0.6 & 1.74 & -1.82 & -7.19 \\
\hline 23 & -1.15 & 0.38 & 1.77 & -0.87 & -5.48 \\
\hline 24 & -1.88 & 0.6 & 1.95 & -1.59 & -6.36 \\
\hline 25 & -2.23 & 0.35 & 1.51 & -1.94 & -7.71 \\
\hline 26 & -2.55 & -0.76 & -0.69 & -2.26 & -6.44 \\
\hline 29 & -1.83 & -0.4 & 0.26 & -1.54 & -5.11 \\
\hline 32 & -1.5 & -0.18 & 0.53 & -1.18 & -6.12 \\
\hline 33 & -1.84 & -0.42 & 0.1 & -1.55 & -5.8 \\
\hline 34 & -1.31 & 0.18 & 1.26 & -1.02 & -4.73 \\
\hline 36 & -2.11 & 0.44 & 1.69 & -1.02 & -7.44 \\
\hline 43 & -2.82 & -0.91 & -0.85 & -2.53 & -6.4 \\
\hline 45 & -1.16 & -0.47 & -0.06 & -0.87 & -5.6 \\
\hline 47 & -1.55 & -0.03 & 0.77 & -1.26 & -6.5 \\
\hline 48 & -1.68 & 0.2 & 1.3 & -1.39 & -6.2 \\
\hline 49 & -1.28 & 0.55 & 2.12 & -1.5 & -6.3 \\
\hline 50 & -1.44 & 0.22 & 1.38 & -1.15 & -6.41 \\
\hline Min & -2.82 & -0.95 & -0.85 & -2.53 & -8.04 \\
\hline Max & -1.15 & 0.95 & 3.07 & -0.87 & -4.73 \\
\hline Mean & -1.95 & 0.17 & 1.27 & -1.66 & -6.66 \\
\hline
\end{tabular}


Table 5. Saturation indices of the Miocene groundwater samples using SOLMINEQ.GW program.

\begin{tabular}{cccccc}
\hline Serial No. & Anhydrite & Calcite & Dolomite & Gypsum & Halite \\
\hline 27 & -0.96 & -0.09 & 1.11 & -0.68 & -3.54 \\
28 & -0.47 & -0.12 & 0.66 & -0.19 & -4.35 \\
30 & -1.89 & -0.38 & 0.27 & -1.6 & -5.28 \\
31 & -1.15 & 0.4 & 1.63 & -0.87 & -4.89 \\
35 & -0.34 & 0.15 & 1.36 & -0.1 & -4 \\
37 & -0.61 & -0.64 & -0.52 & -0.32 & -4.2 \\
38 & -1.7 & 0.32 & 1.56 & -1.4 & -5.27 \\
39 & -1.18 & 0.03 & 0.75 & -0.89 & -4.71 \\
40 & -1.19 & 0.36 & 1.53 & -0.9 & -4.7 \\
41 & -0.44 & 0.67 & 1.75 & -0.15 & -4.98 \\
42 & -1.34 & 0.17 & 1.27 & -1.1 & -5.42 \\
44 & -1.37 & -0.63 & -0.37 & -1.08 & -6.08 \\
46 & -1.3 & 0.14 & 1.19 & -1 & -5.5 \\
Min & -1.89 & -0.64 & -0.52 & -1.60 & -6.08 \\
Max & -0.34 & 0.67 & 1.75 & -0.10 & -3.54 \\
Mean & -1.07 & 0.03 & 0.94 & -0.79 & -4.84 \\
\hline
\end{tabular}

dolomite tend to be precipitated causing reduction of matrix permeability and may cause co-precipitation of pollutants.

\subsubsection{Redox Potential and Dissolved Oxygen}

The redox (Reduction-Oxidation) state of water exerts significant control on its chemistry. Redox conditions influence both the solubility and stability of many common parameters that can control the toxicity or mobility of some contaminants, [28]. The redox potential of groundwater typically varies between -400 and $+800 \mathrm{mV}$ and different (bio) chemical reaction will only occur under specific redox conditions. Aerobic biodegradation of organic contaminants generally occurs under a redox potential greater than $+150 \mathrm{mV}$. Mildly reducing conditions occurs between $\mathrm{Eh}+50$ and $-150 \mathrm{mV}$. Highly reducing conditions occur less than $-200 \mathrm{mV}$ where biological degradation takes place as a result of iron reduction, Sulphate reduction and $\mathrm{CO}_{2}$ reduction (methanogenesis), [28].

The Eh, $\mathrm{pH}$ and dissolved oxygen concentration have been determined in situ for a seven chosen groundwater samples. The Eh values of these samples range between 305 and $370 \mathrm{mV}$ which are relevant to an aerobic biodegradation. This is also indicated by the measured values of their dissolved oxygen content that vary in the range from 2.69 to $9.01 \mathrm{mg} / \mathrm{l}$ i.e. $>0.5 \mathrm{mg} / \mathrm{l})$. The graphical relationship of Eh and $\mathrm{pH}$ of the study samples, (Figure 8), helps in the determination of the solute species of certain mobility and stability (less mobile species are more relevant to natural attenuation). 


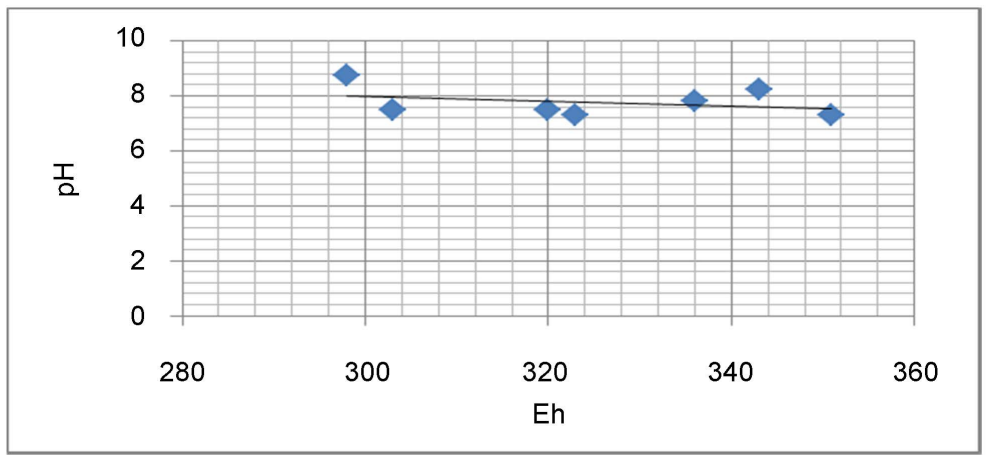

Figure 8. The $\mathrm{pH}$ vs. Eh of some selected groundwater samples.

\subsection{Analytical Expression of Natural Attenuation Capacity of Some Selected Radioisotopes}

The term natural attenuation capacity (NAC), refers to the quantity given in the previous equation that represents the slope of the solute concentration profile along a flowpath, which has units of $\mathrm{m}^{-1}$. Conceptually, it may be thought of as the contaminant lowering capacity of an aquifer per meter of flow path.

To explore the natural attenuation capacity of the groundwater system in Inshas area, where Nuclear Research Reactors exists, six radioisotopes $\left({ }^{3} \mathrm{H},{ }^{14} \mathrm{C}\right.$, ${ }^{60} \mathrm{Co},{ }^{59} \mathrm{Ni},{ }^{99} \mathrm{Tc}$, and ${ }^{90} \mathrm{Sr}$ ) have been selected as being of high retention time and covering a wide range of decay rate. The hydrogeologic parameters of the groundwater system under study ( $\mathrm{v}, \mathrm{D}, \mathrm{k} . .$.$) has been reviwed [29].$

The attenuation capacity has been calculated for the six radioisotopes and repeated at five different values of velocities) $0.04 \mathrm{~m} / \mathrm{d}, 0.2 \mathrm{~m} / \mathrm{d}, 0.3 \mathrm{~m} / \mathrm{d}, 0.4 \mathrm{~m} / \mathrm{d}$, and $1 \mathrm{~m} / \mathrm{d}$ ) to insight the sensitivity of the pollutant attenuation as a result of changing the velocity. The attenuation capacity is increased by decreasing of velocity and completely vanishes at a determintal high velocity. (Figure 9) shows the inverse relation between velocity and natural attenuation capacity for the radioisotopes under concern. If natural attenuation capacity is not satisfactory, enhancement can be done (intensionally) by decreasing the velocity by any of the hydrogeological means. Enhancement may also be intensionally performed by interference with the system properties that affect hydrodynamic dispersion.

\section{Conclusion}

The natural potentiality of groundwater systems to attenuate the contaminants spread and toxicity is on one side affected by nature of contaminant and on the other side affected by the hydrogeochemical, biogeochemical, hydrogeological and physical, characteristics of the system. The natural ability of the groundwater system of the northeast Cairo to limit the distribution of pollutants have been discussed through treating the physical characteristics of the system, the hydrochemical and isotopic composition of collected groundwater samples, and analytical simulation of the contaminant retardation along flow path. The indexes of contamination vulnerability, adsorption and cation exchange as well as solute saturation indicates that the groundwater of the Miocene aquifer in the study 


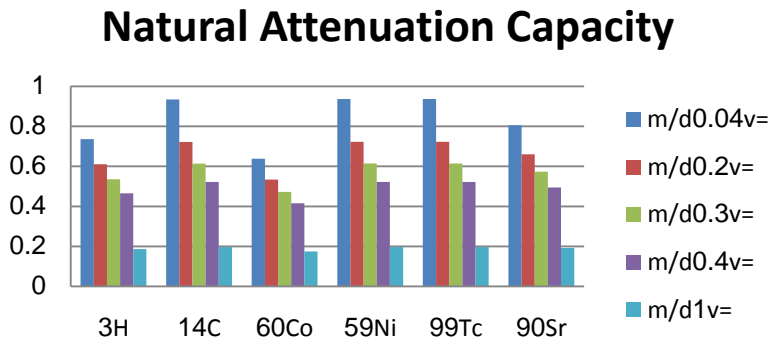

Figure 9. The calculated Natural Attenuation Capacity "NAC" data at different velocities for the concerned radioisotopes.

area has a high natural remediation potential and that of the Quaternary is intermediate. The clay content of the unsaturated zone and water bearing formations, the depth to groundwater and its velocity, $\mathrm{DO}$ and $\mathrm{pH} / \mathrm{Eh}$ values are the factors that control the potential of natural remediation in the study area. The high natural remediation potential of Miocene aquifer is related to its high clay content that decreases groundwater velocity and causes adsorption and also to the high depth to water that retards the flow and contaminants reach. The Quaternary aquifer is, on the other hand, more renewable, lower in residence time and of less clay content. The protectability of the Quaternary aquifer could be increased by dealing with the groundwater velocity attributes.

\section{References}

[1] Wiedemeier, T.H., Swanson, M.A., Moutoux, D.E., Gordon, E.K., Wilson, J.T., Wilson, B.H., Kampbell, D.H., Haas, P.E., Miller, R.N. and Hansen, J.E. (1998) Technical Protocol for Evaluating Natural Attenuation of Chlorinated Solvents in Groundwater. USEPA Office of Research and Development, Washington DC.

[2] Linda Stone, P.G. (2016) Final Report on Monitored Natural Attenuation Evaluation and Application in the Lahontan Region March 2016. Staff of the Lahontan Regional Water Board. http://www.waterboards.ca.gov/lahontan/

[3] Ouvrard, S., Chenot, E.-D., Masfaraud, J.-F. and Schwartz, C. (2013) Long-Term Assessment of Natural Attenuation: Statistical Approach on Soils with Aged PAH Contamination. Biodegradation, 24, 539-548. https://doi.org/10.1007/s10532-013-9618-5

[4] Chapelle, F.H., Widdowson, M.A., Brauner, J.S., Mendez, E. and Casey, C.C. (2003) Methodology for Estimating Times of Remediation Associated with Monitored Natural Attenuation. USGS WRIR, 03-4057.

[5] Carey, M., Finnamore, J., Morrey, M. and Marsland, P. (2000) Guidance on the Assessment and Monitoring of Natural: Attenuation of Contaminants in Groundwater. R and D Publication-Environment Agency.

[6] Golder Associates Ltd. (2010) Technical Guidance for Contaminated Sites. Groundwater Investigation in Site Assessment.

http://www2.gov.bc.ca/assets/gov/environment/air-land-water/siteremediation/docs /bulletins/tech-guide-gw.pdf

[7] RR-614 (2014) Guidance on Natural Attenuation for Petroleum Releases. Wisconsin Department of Natural Resources, Madison.

[8] Shatta, A.A., Abdel Salam, A.A. and Harga, A.A. (1979) Soil Map of the Eastern Delta Region. In: Tumilat-Suez, E., Ed., 4th Report. Internal Report, Academy of 
Scientific Research Technology, Cairo, 89.

[9] Said, R. (1990) The Geology of Egypt. Elsevier, Amsterdam.

[10] El Shazly, E.M., Abd El Hady, M.A., El Shazly, M.M., El Kassas, I.A., El Ghawaby, M.A., Salman, A.B. and Morsi, M.A. (1975) Geology and Groundwater Potential Studies of El Ismailia Master Plan Study Area. Remote Sensing Research Project, Academy of Scientific Research and Technology, Cairo, 24-35.

[11] El Sayed, S.A. (2005) Hydrogeological Studies and Application of the Environmental Isotopes Techniques on the Groundwater Resources in the Northeast Greater Cairo, Egypt. PhD Thesis, Ain Shams University, Cairo, 105.

[12] Hefny, K. (1983) Land-Use and Management Problems in the Nile Delta (Egypt). Nature and Resources, 18, 22.

[13] Mohamed, F.A.A. (2009) Environmental Assessment of Groundwater Resources at Northeast Cairo.

[14] American Society for Testing and Materials (ASTM) (2002) Water and Environmental Technology. Annual Book of ASTM Standards, Sec., 11: 11.01 and 11.02, West Conshohocken.

[15] Foster, S.S.D. (1998) Groundwater Recharge and Pollution Vulnerability of British Aquifers: A Critical Review. In: Robins, N.S., Ed., Groundwater Pollution, Aquifer Recharge and Vulnerability, Special Publications, Vol. 130, Geological Society, London, 7.

[16] Ghazavi, R. and Ebrahimi, Z. (2015) Assessing Groundwater Vulnerability to Contamination in an Arid Environment Using DRASTIC and GOD Models. International Journal of Environmental Science and Technology, 12, 2909-2918. https://doi.org/10.1007/s13762-015-0813-2

[17] Thorne, D. (1951) Alkali Soils: Their Formation, Properties and Reclamation. W. P. Kelley. New York: Reinhold, 1951. 176 p. \$5.00. Science, 114, 558.

[18] Freeze, R.A. and Cherry, J.A. (1979) Groundwater. Prentice-Hall, Englewood Cliffs, 604.

[19] Maidment, D.R. (1993) Handbook of Hydrology. McGraw-Hill, New York.

[20] Chapra, S.C. (1996) Surface Water-Quality Monitoring. McGraw Hill, New York, 844.

[21] Hamza, M., Swailem, F. and Abd El-Monem, A. (1982) Groundwater Hydrology of Wadi El-Natrun. III. Distribution of Radium and Deuterium Contents. Isotope and Radiation Research, 14, 9-17.

[22] Salem, W. (1996) Application of Isotopic and Hydrochemical Techniques to Study Groundwater in the Eastern Nile Delta and Assessment of Pollution in Lake Manzala. PhD Thesis, Faculty of Engineering, Cairo University, Cairo.

[23] Sonntag, C., Klitzsch, E., Lohnert, E.P., El-Shazly, E.M., Munnich, K.O., Junghans, C., Thorweihe, U., Weistroffer, K. and Swailem, F.M. (1978) Isotope Hydrology. Proceedings of a Symposium, Vol. 2, Vienna, 2-6 October 1978, 569.

[24] Hassan, T.M., Awad, M.A. and Hamza, M.S. (1996) Study of Recharge of the Phreatic Aquifers, South East Egypt, Using Environmental Isotopes and Hydrochemistry. Arab Journal of Nuclear Science and Applications, 29, 21.

[25] Saleh, A., Al-Ruwaih, F. and Shehata, M. (1999) Hydrogeochemical Processes Operating within the Main Aquifers of Kuwait. Journal of Arid Environments, 42, 195 209. https://doi.org/10.1006/jare.1999.0511

[26] McLean, L.A., Roscoe, J., Jørgensen, N.K., Gorin, F.A. and Cala, P.M. (2000) Malignant Gliomas Display Altered pH Regulation by NHE1 Compared with Nontrans- 
formed Astrocytes. American Journal of Physiology-Cell Physiology, 278, C676C688.

[27] Solmineq, G.W. (1999) Geochemical Application and Modeling Software. LTD., Emadton, Alberta.

[28] Ohio, E.P.A. (2014) Reduction-Oxidation (Redox) Control in Ohio's Groundwater Quality, Division of Drinking and Ground Waters. Technical Series on Ground Water Quality.

[29] Mahmoud, N.S. and EL-Hemamy, S.T. (2005) On the Possible Leakage of ET-RR1 Liquid Waste Tank: Hydrological and Migration Modes Studies. The Scientific World Journal, 5, 234. https://doi.org/10.1100/tsw.2005.34

Submit or recommend next manuscript to SCIRP and we will provide best service for you:

Accepting pre-submission inquiries through Email, Facebook, LinkedIn, Twitter, etc. A wide selection of journals (inclusive of 9 subjects, more than 200 journals)

Providing 24-hour high-quality service

User-friendly online submission system

Fair and swift peer-review system

Efficient typesetting and proofreading procedure

Display of the result of downloads and visits, as well as the number of cited articles

Maximum dissemination of your research work

Submit your manuscript at: http://papersubmission.scirp.org/

Or contact gep@scirp.org 